\title{
ІНФОРМАЦЙНО-АНАЛІТИЧНА КОМПЕТЕНТНІСТЬ МАЙБУТНІХ ЛІКАРІВ: КРИТЕРІЇ, ПОКАЗНИКИ ТА РІВНІ СФОРМОВАНОСТІ
}

Лобач Н. В. Інформаційно-аналітична компетентність майбутніх лікарів: критерії, показники та рівні сформованості.

У статті розглядається поняття та структура інформаційно-аналітичної компетентності майбутніх лікарів, розкрито зміст поняття «критерій», визначені критерії, рівні та показники сформованості зазначеної компетентності в освітньому середовищі вищого медичного навчального закладу.

Ключові слова: інформаційно-аналітична компетентність, критерії, показники, рівні сформованості.

Лобач Н. В. Информационно-аналитическая компетентность будущих врачей: критерии, показатели и уровни сформированности.

В статье рассматривается понятие и структура информационно-аналитической компетентности будущих врачей, раскрыто содержание понятия «критерий», определены критерии, уровни и показатели сформированности указанной компетентности в образовательной среде высшего медицинского учебного заведения.

Ключевые слова: информационно-аналитическая компетентность, критерии, показатели, уровни сформированности.

Lobach N. V. Information and analytical competence of future doctors: indicators, criteria and levels of formation.

This article considers the concepts and structure of information and analytical competence of future doctors, discloses the concept of «criterion», defines the criteria and competence's indicators of formation specified in the educational environment of higher medical school.

Key words: information and analytical competence, criteria, indicators, levels of formation.

Стрімкий розвиток біологічної, медичної та фармацевтичної науки, зумовив зростання і поглиблення знань щодо закономірностей і функціонування людського організму, в наслідок чого постійно з'являються нові методи діагностування i лікування, при цьому швидко збільшується обсяг інформації, що необхідна лікарям у практичній діяльності. Тому підготовка висококваліфікованого, конкурентоспроможного фахівця медичної галузі неможлива без високого рівня сформованості d нього інформаційно-аналітичної компетентності.

Поняття компетентнісного підходу $\mathrm{d}$ системі освіти було і залишається предметом дослідження багатьох вітчизняних i зарубіжних науковців. Зокрема, Н. Баловсяк, І. Бех, В. Болотов, С. Гончаренко, І. Зимня, Е. Зеєр, В. Кремень, В. Лозова, Дж. Равена, О. Савченко, Ю. Скрипкіна, С. Тришина, А. Хуторський та інші розглядали підвищення якості вищої освіти на компетентнісній основі. Н. Баловсяк, Я. Галета, М. Головань, О. Значенко досліджували проблему формування інформаційної культури й інформаційної компетентності фахівця.

Різноманітні аспекти інформаційно-аналітичної діяльності розглядали

О Гайдамак, Є. Карпенко, О. Кобєлєв, П. Конотопов, О. Назначило, Н. Рижова, О. Скафа, Н. Сляднева, Р. Сорока та інші. 
Дослідження формування і розвитку дмінь роботи з інформацією здійснювали такі науковці, як: Н. Гендіна, Н. Морзе, В. Клочко, М. Жалдак, Н. Сляднєва, А. Горячов та інші.

Утім, в наявних дослідженнях не знайшли належного висвітлення питання визначення поняття «інформаційно-аналітична компетентність майбутніх лікарів» та визначення критеріїв, рівнів та показників ії сформованості.

Метою дослідження є визначення сутності поняття «інформаційно-аналітична компетентність майбутніх лікарів» та теоретичне обгрунтування критеріїв i показників іiі сформованості, що потребує у свою чергу аналізу ключових понять, як: інформаційно-аналітична діяльність, критерій, показник і рівень.

Отже, звернення до поняття «інформаційно-аналітична компетентність» обумовлено кількома чинниками:

- пред'явлення високих вимог до сучасного фахівця;

- глобальна інформатизація суспільства;

- збільшення обсягу інформації, іiі форм, видів та засобів оброблення;

- необхідність навчання упродовж життя.

Зважаючи на те, що нині головною особливістю навчальної діяльності студента в освітньому середовищі $є$ здобуття нових знань, то стає очевидним, що в бурхливому і швидко змінному потоці інформації від нього вимагається не тільки вміння знаходити, а й уміння якісно аналізувати, порівнювати, структурувати, узагальнювати отриману інформацію, оцінювати ііі та робити висновки. Це говорить про необхідність формування у студентів знань, умінь якісного виконання інформаційно-аналітичної діяльності.

Останні десятиліття, реагуючи на зміни, що відбуваються в інформаційному суспільстві, а саме: збільшення обсягу інформації, поява нових інформаційних ресурсів, методів та засобів іiі оброблення та зберігання, аналітична діяльність має тенденцію до швидкого динамічного розвитку. У зв'язку з цим все частіше аналітика ототожнюється 3 інформаційною аналітикою. Як стверджує Н. Сляднєва [4], інформаційна аналітика займається виробництвом нового знання на основі переробки наявної інформації задля оптимізації прийняття рішень. Сучасна інформаційна аналітика - складна комплексна діяльність, яка спирається як на природний інтелект, так і на комп'ютерні технології оперування інформаційними масивами, методи математичного моделювання процесів і тощо. Науковець визначає, що аналітика містить три компоненти: сукупність знань предметної галузі (галузевий компонент), володіння аналітичними методами (функціональний компонент) та певний тип структури особистості (особистісний компонент).

Отже, ми можемо погодитися з О. Матвієнко [2], яка вважає, що до аналітичної діяльності належать такі процедури і процеси інтелектуальної діяльності, які мають ознаки творчості, породжують нову інформацію, дозволяють виявляти нові проблеми або їх аспекти та пропонують нетрадиційні способи їх розв'язання.

Р. Сорока, М. Сорока [5] виокермлюють два рівні інформаційно-аналітичної діяльності:

1) інформаційний рівень, що полягає в пошуку, збиранні, зберіганні, поширенні інформації;

2) аналітичний рівень, що полягає в узагальненні, класифікації інформації, іiі аналізі й перетворенні, розробленні висновків, пропозицій, рекомендацій і прогнозів.

Отже, під інформаційно-аналітичною діяльністю майбутніх лікарів будемо розуміти таку діяльність, яка дозволяє студенту вільно орієнтуватися в освітньому 
середовищі вищого медичного навчального закладу, приймати участь у його формуванні, а також успішно реалізувати свої освітні та інформаційні потреби.

Аналіз наукової літератури дав нам змогу визначити, що компетентність $\epsilon$ інтегративною характеристикою особистості, що виявляється у вмінні користуватися набутими компетенціями, та повноваження, які має фахівець у визначеній галузі і описує кінцевий результат навчання. Під компетенцією розуміємо отримані знання, вміння, навички у визначеній сфері діяльності, сукупність особистісних якостей, мотивацію, що необхідна людині для ефективного виконання поставленого перед нею завдання як у професійній діяльності, так і в повсякденному житті.

Отже, у нашому дослідженні інформаційно-аналітичну компетентність майбутніх лікарів ми будемо розуміти як складник їх професійної компетентності, що відображає готовність та здатність тих, хто навчається, застосовувати здобуті знання, вміння, навички в сукупності 3 їх особистісними якостями під час роботи 3 інформацією різних видів і форм представлення (традиційній, електронній), а також здатність проводити іiі аналітико-синтетичну обробку задля отримання якісно нового знання, що дає можливість забезпечити процес прийняття відповідальних рішень у різних сферах діяльності, зокрема професійній.

У структурному плані інформаційно-аналітична компетентність майбутніх лікарів відображає цілісну єдність ціннісно-мотиваційного, когнітивного, діяльніснотехнологічного та рефлексивно-оцінного компонентів.

Ціннісно-мотиваційний компонент спонукає майбутніх фахівців до здійснення пошуку професійно значущої інформації, потреби, прагнення, зацікавленість до освіти та самоосвіти, впевненість у необхідності формування інформаційноаналітичної компетентності. О Шехонін, В Тарликов [6] уважають, що мотивація спонукає студентів до зацікавленості у будь-якому виді діяльності та у своїх результатах навчання та $є$ одним 3 основних критеріїв поділу студентів на групи 3 високим, середнім і низьким рівнем успішності навчальної діяльності.

Когнітивний компонент формує знання методів та технологій пошуку, оброблення, збереження та аналітико-синтетичної переробки інформації в єдності теоретичних, методичних та технологічних знань.

Діяльнісно-технологічний компонент відображає рівень володіння знаннями про алгоритми, способи, засоби ефективного пошуку, використання та здатність проводити аналітико-синтетичну переробку інформації.

Оцінно-рефлексивний компонент забезпечує усвідомлення особистісного досвіду в інформаційно-аналітичній діяльності, оцінку отриманого результату, знаходження помилок та вміння їх виправляти.

Результат формування інформаційно-аналітичної компетентності майбутніх лікарів не можна оцінити без визначення відповідних критеріїв і показників, адже підготовка фахівця у такому випадку втрачає будь-який сенс, оскільки є невизначений іiї кінцевий результат.

У словнику-довіднику з професійної педагогіки А. Семенової [3] критерій (від грец. кritērion - засіб для судження) - це ознака, завдяки якій відбувається оцінка, визначення або класифікація явища чи процесу. Показник - це явище або подія, за яким можна судити про динаміку певного процесу.

Дослідження О. Бондар [1] показали, що критерії мають бути: об'єктивними; передбачати найістотніші, основні аспекти досліджуваного явища; охоплювати його типові характеристики; формулюватися ясно, коротко, чітко; вимірювати саме те, що перевіряє дослідник; відображати динаміку вимірюваної якості у просторі й часі; за можливістю охоплювати основні види професійної діяльності; розкриватися низку 
ряд показників, за ступенем вияву яких можна судити про більший чи менший ступінь виразності окремо взятого критерію.

У якості критеріїв ефективного формування інформаційно-аналітичної компетентності визначаємо такі:

- $\quad$ мотиваційний, показниками якого $є$ : активність студентів до виконання інформаційно-аналітичної діяльності; усвідомлення значущості інформаційноаналітичної компетентності в майбутній професійній діяльності;

- когнітивний, показниками якого постають знання про сутність, зміст, методи та способи інформаційно-аналітичної діяльності в освітньому середовищі; знання норм інформаційної етики та інформаційної культури;

- діяльнісний, показники якого мають визначати рівень комп'ютерної грамотності, аналітичного мислення, наявність умінь та навичок пошуку, відбору, використання та презентації отриманої інформації;

- рефлексивний, показники якого повинні визначати самооцінку власної інформаційно-аналітичної компетентності студентів; виробленість потреби до формування інформаційно-аналітичної компетентності.

Наявність цих критеріїв дає змогу визначити рівень сформованості інформаційно-аналітичної компетентності у майбутніх лікарів, ми пропонуємо виділяти три рівні: низький, достатній, високий.

Низький.

Мотиваційний. У майбутнього лікаря наявна позитивна мотивація для роботи 3 інформаційними ресурсами.

Когнітивний. Знання алгоритму інформаційно-аналітичної діяльності у студента практично відсутнє.

Діяльнісний. Майбутній лікар володіє початковими вміннями працювати 3 інформацією, але не завжди може оцінити іiі достовірність та якість; навички роботи 3 інформаційно-комунікаційними технологіями на основі елементарних дій.

Рефлексивний. Майбутній фахівець не здатний адекватно оцінити результати своєї діяльності, не помічає допущені в роботі помилки; прагнення до поповнення й отримання знань та навичок носить фрагментарний характер, але усвідомлюється їх недостатність.

\section{Достатній.}

Мотиваційний. Майбутній лікар усвідомлює потребу в додатковій інформації; виявляє зацікавленість до самоосвіти, самонавчання в освітньому середовищі.

Когнітивний. Володіє знаннями про структуру різноманітних джерел інформації, методів пошуку, оброблення, аналізу інформації

Діяльнісний. Достатньою мірою володіє деякими (але не всіма) прийомами пошуку інформації, основними навичками роботи 3 інформаційно-комунікаційними технологіями; може визначити якість і достовірність інформації, володіє початковими навичками аналізувати отриману інформацію

Рефлексивний. Майбутній лікар усвідомлює недостатнє володіння необхідними знаннями та вміннями, бачить свої недоліки в роботі, але не завжди спроможний встановити їх причини; прагнення до підвищення рівня своєї інформаційноаналітичної компетентності недостатньою мірою підкріплено роботою над собою.

Високий.

Мотиваційний. Майбутній лікар прагне до виконання інформаційної діяльності; робота в освітньому середовищі набуває особистісного характеру, самоосвіта стає невід'ємною частиною його діяльності.

Когнітивний. Студент володіє глибокими, систематизованими знаннями про 
освітнє середовище вищого медичного навчального закладу, що виявляються ву повній самостійності використання його у інформаційно-аналітичній діяльності; дотримується норм, що регламентують використання інтелектуальної власності; знає сутність аналітико-синтетичного оброблення інформації.

Діяльнісний. Майбутній лікар вільно володіє різними прийомами пошуку інформації 3 будь-яких джерел за найкоротший час у межах навчальної та позанавчальної діяльності, у нього не виникає труднощів під час роботи 3 інформаційно-комунікаційними технологіями. Уміє працювати із різними джерелами інформації, швидко оцінює якість та достовірність отриманої інформації, володіє навичками аналізувати, порівнювати, структурувати, анотувати та реферувати інформацію.

Рефлексивний. Майбутній лікар усвідомлює потребу в особистісно значущій інформації, адекватно оцінює результати своєї діяльності, помічає помилки в роботі і прагне їх виправити; сформована потреба в постійному підвищенні рівня інформаційно-аналітичної компетентності.

Отже, можемо зазначити, що критерії оцінки сформованості інформаційноаналітичної компетентності майбутніх лікарів $є$ необхідними для визначення того, наскільки вони виявляться адаптованими, підготовленими до виконання інформаційно-аналітичної діяльності, навчаться критично оцінювати інформацію, приймати відповідні рішення, а також володіти навичками творчо працювати 3 інформацією як у друкованому, так і в електронному вигляді, тобто бути загалом конкурентоспроможною особистістю на ринку праці.

\section{Література}

1. Бондар О. В. Критерии и показатели сформированности информационной культурі менеджеров организации в последипломной подготовке / О.В.Бондар // Педагогічний альманах. - 2012. - Випуск 14, - С. 134-139. 2. Матвіснко О. В. Основи інформаційного менеджменту : [навч. посіб.] / О. В. Матвієнко. - К : Центр навчальної літератури, 2004. - 128 с. 3. Словник-довідник з професійної педагогіки / за ред. А. В. Семенової. - Одеса: Пальміра, 2006. - 364 с. 4. Сляднева Н. А. Информационно-аналитическая деятельность : проблемы и перспективы [Электронный ресурс] / Н. А. Сляднева // Информационные ресурсы России. - 2001.№ 2. - С. 14-21. - Режим доступа : http://abfarida.narod.ru/sladneva.htm 5. Сорока P. С. Значення інформаційно-аналітичної діяльності в забезпеченні економічної безпеки підприємства / Р. С. Сорока, М. П. Сорока // Науковий вісник НЛТУ України: Збірник науково-технічних праць. - Львів: РВВ НЛТУ України. - 2012.- Вип. 22.13.С. 317-322. 6. Шехонин А. А. Оценивание компетенции в сетевой среде вуза / А. А. Шехонин, В. А. Тарлыков // Высшее образование в России. - 2009. - № 9. C. 17-24. 